Article

\title{
Does High-Speed Rail Influence Urban Dynamics and Land Pricing?
}

\author{
Panrawee Rungskunroch ${ }^{1,2,3}$, Yuwen Yang ${ }^{1}$ and Sakdirat Kaewunruen ${ }^{1,2, * \mathbb{D}}$ \\ 1 School of Civil Engineering, University of Birmingham, Birmingham B15 2TT, UK; \\ PXR615@student.bham.ac.uk (P.R.); yywmol@foxmail.com (Y.Y.) \\ 2 Birmingham Centre for Railway Research and Education (BCRRE), University of Birmingham, \\ Birmingham B15 2TT, UK \\ 3 Institute of Transportation Study (ITS), University of California, Berkeley, CA 94720, USA \\ * Correspondence: s.kaewunruen@bham.ac.uk
}

Received: 27 February 2020; Accepted: 1 April 2020; Published: 9 April 2020

check for

\begin{abstract}
At present, many countries around the world have significantly invested in sustainable transportation systems, especially for high-speed rail (HSR) infrastructures, since they are believed to improve economies, and regenerate regional and business growth. In this study, we focus on economic growth, dynamic land use, and urban mobility. The emphasis is placed on testing a hypothesis about whether HSRs can enable socio-economic development. Real case studies using big data from large cities in China, namely Shanghai province and Minhang districts, are taken into account. Socio-technical information such as employment rate, property pricing, and agglomeration in the country's economy is collected from the China Statistics Bureau and the China Academy of Railway Sciences for analyses. This research aims to re-examine practical factors resulting from HSR's impact on urban areas by using ANOVA analysis and dummy variable regression to analyse urban dynamics and property pricing. In addition, this study enhances the prediction outcomes that lead to urban planning strategies for the business area. The results reveal that there are various effects (i.e., regional accessibility, city development plans, and so on) required to enable the success of HSR infrastructure in order to enrich urban dynamics and land pricing. This paper also highlights critical perspectives towards sustainability, which are vital to social and economic impacts. In addition, this study provides crucial perspectives on sustainable developments for future HSR projects.
\end{abstract}

Keywords: high-speed rail; urban dynamic; land price; city development; sustainable development; sustainability

\section{Introduction}

Since 1964 and the birth of high-speed rail (HSR) in Japan, HSR has catalysed high impacts on socio-economic dynamics and stimulated economic growth in many continents around the world $[1,2]$. The Tokaido Shinkansen has linked Tokyo and Osaka, and the service has had an extreme impact on Japanese lifestyle in terms of the economy and society [3]. After launching the new services on Kyushu Shinkansen, the services have increased accessibility and expanded business-centric areas. Moreover, the ultimate benefits from the HSR have been revealed in terms of commercial factors such as increasing the employment rate, average income, production, and property prices $[4,5]$. The success of these HSR projects has provoked other countries to launch their own HSR services. For those reasons, HSR has turned out to be the best form of transportation in this era, although it requires a high investment cost for its infrastructure and operation.

Many researchers have studied the impacts of HSR on urban planning in terms of business opportunities and the city's economy. Some people have stated that HSR's influence could not be 
predicted because HSR's dependence on local area may lead to differing land and property values. The commuter traffic impacts positively on the region, such as in economic, political, social, or cultural areas, or the transportation system [6-9]. Moreover, HSR services increase accessibility to various areas, which offers benefits for labour, investment, and industry [9].

There are several arguments about the size of the impact of HSR on the city. Some researchers mentioned that the impact of HSR on the building and land price could be estimated from the city's commercial and surrounding facilities [9]. Similarly, some evidence has revealed that the size of the impact of HSR is different depending on the characteristics of each area, and HSR was found to have smaller effects in suburban areas than in the city centre $[10,11]$. On the other hand, some researchers argued that the impact of the HSR service could not be estimated in some major cities that were rapidly urbanised before using the HSR service.

This research thus aims to study the socio-economic impacts from the HSR network in terms of population dynamics and land pricing. The benefits of this study will lead to sustainable development with respect to socio-economic factors. This study has been conducted using a long-term dataset from Shanghai province and Minhang district. Moreover, the research is expected to answer the following question: how does HSR impact on land/property price and population dynamics in urban areas? By exploring this research question, the research will intensely discuss important socio-economic factors, i.e., demand and supply of property and land, the location of the business area, and city planning. Moreover, this study provides a prediction analysis based on long-term data collection. Not only does this study show the socio-economic impacts of the HSR network, but business perspectives on the land price are also portrayed. The outcome will be beneficial to landlords, investors and residents.

\section{Research Scope}

\subsection{The Meaning of High-Speed Rail}

The specific definition of HSR in the context of this paper is a rail service with a passenger train that travels at a designed speed of $250 \mathrm{~km} / \mathrm{h}$ or more, with a maximum speed of $250 \mathrm{~km} / \mathrm{h}$ for mixed passenger-freight trains $[12,13]$.

\subsection{Scope of Study on the Impact of the High-Speed Rail on Urbanisation}

This study compares HSR with other modes of transportation, such as aviation, a private car, bus, or other services that are influenced by the high-speed rail services at both a district and regional level. Moreover, the area of the city around the HSR station that could be impacted by HSR has been measured as the focus area in a range of $250-600 \mathrm{~km}$ from the city centre; however, the core catchment area is focused on a radius of $1.2 \mathrm{~km}$ from the HSR station.

\section{Research Methodologies}

\subsection{The Integration between Theory and Case Studies}

This study has combined theoretical research with empirical studies to determine the impact on society. The case study in Shanghai has been compared with the conceptual model and has been analysed through both qualitative and quantitative analyses.

\subsection{Analysis Method}

This research aims at finding the correlation between HSR services and socio-economic development by undertaking both qualitative and quantitative analysis from literature reviews. This research has also used Eviews, which is a reliable statistical software, to define dummy variable regression analyses. The outcome is expected to measure the correlation of HSR services with urban dynamics and land pricing regarding the city of Shanghai, China. 
Regarding the analysis of variance (ANOVA) in Equation (1), it is applied to this research for testing the impact on population dynamics and property pricing from the HSR service:

$$
\mathrm{Y}_{\mathrm{i}}=\mathrm{C}+\mathrm{dX} \mathrm{X}_{1}
$$

where $Y_{i}=$ the dummy variable; $X_{1}=$ dependent variables, which, in this study, refer to population dynamics or property price.

The outcome will be represented in a time series unit, so it is necessary to address the autocorrelation problem. The adding variable AR (1) aims to correct the autocorrelation value:

$$
\mathrm{Y}_{\mathrm{i}}=\mathrm{C}+\mathrm{dX}_{1}+\mathrm{AR}(1)
$$

where $Y_{i}=$ the dummy variable; $X_{1}=$ dependent variables, which, in this study, refer to population dynamics or property price; $\mathrm{AR}=$ autocorrelation.

\section{Literature Review}

The World Bank report revealed some of the regional economic impacts of HSR. There are three areas to the report, consisting of Japan the United Kingdom (UK), and Germany. The differentiation between those frameworks was based on the measurement of each country's economy. Germany used largely qualitative procedures to measure the impact of HSR services on the country's economy. The UK applied the equilibrium model through the HS2 project in terms of a cost-benefit analysis. Furthermore, Japan selected the basic model of supply, demand, and price to evaluate the regional impact of the HSR, such as on tourism and employment rate [14-16].

In China, some research illustrated that the growth of a city's economy did not relate to transportation in the city. In addition, improved transportation infrastructure increased average productivity and contributed to additional economic growth. Moreover, transport projects could bring considerable benefits to China at the current stage of development. An apparent growth in business, average working hours, productivity, and amount of labour due to the Beijing-Shanghai and Wuhan-Guangzhou HSR lines was noted [15].

\subsection{Accessibility of the HSR Services}

An increase in the accessibility of areas due to HSR services was found to be a key driver in a study to find the impact of HSR on population dynamics and land pricing $[16,17]$. Many researchers reported that HSR services have impacted regional accessibility [18]. However, the local effects of HSR could not contribute to directly increasing productivity. The availability of the city's products, business areas, and residential areas were the outcomes of the efficient public transportation system, which directly affected the population in terms of employment rate, as illustrated in Figure 1 [19]. Moreover, reducing travel time and cost between two regions can genuinely enhance the productivity of the city due to agglomeration benefits [20]; in other words, the competitiveness of the city requires a suitable transportation network.

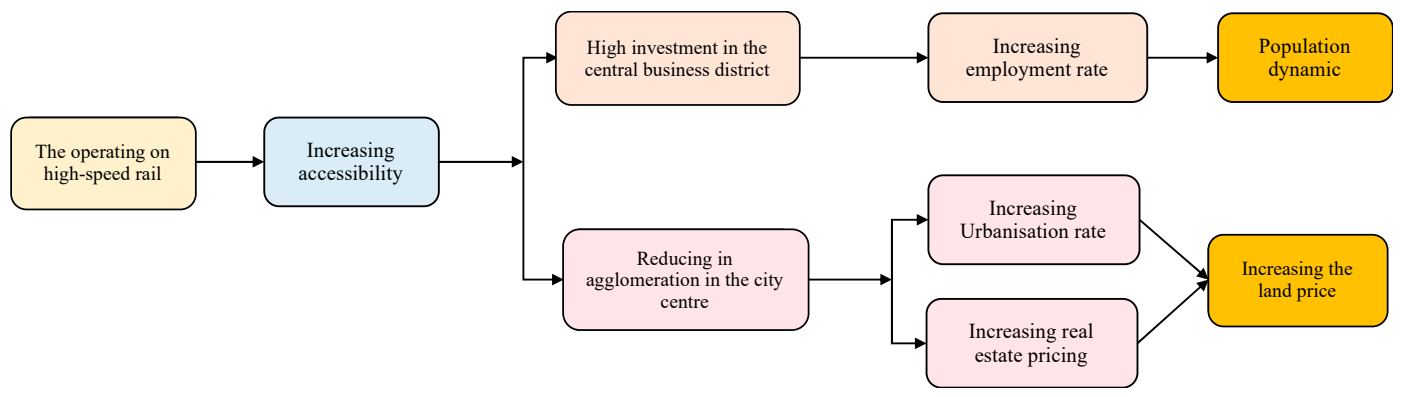

Figure 1. The social impacts of high-speed rail (HSR) operation. 
Both street networks and public transportation have increased regional accessibility $[5,21]$. The HSR service typically accounts for the creation of transportation hubs in the city for passenger services and goods conveyance; in other words, the creation of optimal locations for business operation in a region is a product that stems from the transportation system. Therefore, the development of the social impact regarding society and the economy mostly requires transportation accessibility. The relationship between HSR services and economic value can be displayed in a Geographic Information System (GIS) [22].

There are a large variety of aspects and models to measure accessibility from researchers, as summarised in Figure 1. There are two parts which should be considered in measuring availability, namely the enhancement of the target destinations, such as investment, employment, GDP, and the worthiness of transportation cost from origin to destination, such as transportation time and travel fee [23-25]. Many methods have been used to evaluate the accessibility impact of HSR-for instance, the accessibility measurement of HSR services in European countries by using the weighted average travel time [26]. Moreover, various indicators (i.e., number of accessible areas at the destination, the city's GDP, total travel time) have been applied to regional availability measurements [22]. Many researchers have argued that it is not possible to describe the measurement of the accessibility method in geographical terms [27-30]. Although these techniques have been useful in a small group of the sample set, the method was lacking when analysing some smaller factors, such as the city's attractions, that interact with the people's choice of destination [30]. Furthermore, the research found that there was no relationship between the labour supply and the rate of accessibility [30-32]. Nevertheless, those studies did not address the expansion of business and investment that was affected by the opportunity to travel to a workplace. In addition, inverse balancing factors were used to constrain the movement of people or goods between two locations [33].

A case study in Italy, similarly, showed the impact of HSR services between Milan and Verona on the urban sprawl, as the service could meet local passenger's expectations [34]. However, the expectations of passengers regarding the accessibility varied due to the personal background of commuters.

These discussions contribute to the improvement in HSR's accessibility measurement based on a single passenger-for instance, with respect to the different amount of time taken to travel and the destination $[35,36]$. A study found that a sufficient method to measure travel behaviour was the activity-based approach method [36]. Moreover, another accessibility analysis included other related factors, such as the purpose of travel and utilities at the destination $[37,38]$. A summary of the existing formulas and description are represented in Table 1.

Table 1. Summary of the existing formulas.

\begin{tabular}{|c|c|c|}
\hline Formula & Description & References \\
\hline$A_{i}=\frac{\sum_{\mathrm{j}-1}^{\mathrm{n}}\left(\mathrm{T}_{\mathrm{ij}} \times \mathrm{GDP}_{\mathrm{j}}\right)}{\sum_{\mathrm{j}-1}^{\mathrm{n}} \mathrm{GDP}_{\mathrm{j}}}$ & $\begin{array}{l}\text { where } T_{i j} \text { is the travel time between zones } i \text { and } j \text {, } \\
\text { and GDP }{ }_{j} \text { is the gross domestic product (GDP) of zone } j \text {. }\end{array}$ & [1] \\
\hline$I A A=\frac{\sum_{j=1}^{n}\left(I R_{i j} * P C A E_{j}\right)}{\sum_{j=1}^{n} P C A E_{j}}$ & $\begin{array}{l}\text { where } I R_{i j} \text { is the minimum time between node } i \text { and } j, \\
P C A E_{j} \text { refers to the population in a major urban area }\end{array}$ & [26] \\
\hline$A_{i}=\sum_{j-1}^{n} D_{j} e^{-\beta c_{i j}}$ & $\begin{array}{l}\text { where } c_{i j} \text { is the total travel cost between zones } \\
i \text { and } j \text {, and } D_{\mathrm{j}} \text { is the total number of opportunities in } \\
\text { zone } j .\end{array}$ & {$[27,39]$} \\
\hline$A_{i\left(T \leq T_{\max }\right)}=\sum_{j=1}^{n}\left(\frac{D_{j}}{T_{i j}^{\alpha}} \frac{\sum_{k=1}^{n}\left(\frac{D_{k}}{T_{j k}^{\alpha}}\right)}{\sum_{k=1}^{n}\left(\frac{L_{k}}{T_{j k}^{\alpha}}\right)}\right.$ & $\begin{array}{l}\text { where } A_{i}\left(T \leq T_{\max }\right) \text { is the access in the time range } T_{\max } \\
\text { from zone } i, j \text { is number of accessed zones within } T_{\max } \\
\text { from zone } i, k \text { is all zones within } T_{\max } \text { from zone } j, D_{j} \text { is } \\
\text { the job opportunities in zone } j, \mathrm{~L}_{\mathrm{k}} \text { is the volume of the } \\
\text { job market in zone } k \text {. }\end{array}$ & [29-31] \\
\hline
\end{tabular}


Table 1. Cont.

\begin{tabular}{cll}
\hline Formula & Description & References \\
\hline$A_{i}=\sum_{j=1}^{n}\left(\frac{D_{j}}{B_{j}} f\left(d_{i j}\right)\right)$ & $\begin{array}{l}\text { where } \mathrm{A}_{\mathrm{i}} \text { is the accessibility of jobs in zone } j, \mathrm{~B}_{\mathrm{j}} \text { is the } \\
\text { accessibility of workers in zone } i, \mathrm{O}_{\mathrm{i}} \text { is the number of } \\
\text { residents in zone } i, \mathrm{~d}_{\mathrm{ij}} \text { is the total distance from area } i \text { to } j .\end{array}$ \\
$B_{j}=\sum_{j=1}^{n} \frac{O_{i}}{A_{i}} f\left(d_{i j}\right)$ & $\begin{array}{l}\text { Individual-based accessibility, incorporating spatial and } \\
\text { temporal constraints. }\end{array}$ \\
\hline- & $\begin{array}{l}\text { where } \mathrm{A}_{\mathrm{i}} \text { is the expected utility of individual } i, \mathrm{~V}_{\mathrm{ic}} \text { is the } \\
\text { observable indirect utility of mode } c \text { for the individual } i \\
\text { and } \mathrm{C}_{\mathrm{n}} \text { is the choice set for the person } i .\end{array}$ \\
\hline$A_{i}=\ln \left(\sum_{\forall c \in C_{n}} \exp \left(V_{i c}\right)\right)$ &
\end{tabular}

\subsection{Impact of HSR on Land and Property Prices}

The rise in property prices has been claimed to be one of the benefits of railway accessibility. Many researchers revealed that the impacts of HSR services on property values were different, and various types of railway stations offer different types of trains in their services, such as standard trains, intercity trains, and HSR. It was found that train stations with commuter trains in service have a massive volume of passengers, more than the other stations, due to the number of stops. Thus, the high number of passengers force high demand for property around the train station, which leads to an increase in property prices [39]. Furthermore, a study on the impact of railway stations on property value in the USA by using meta-analysis found that a commuter railway station provided a higher positive impact on the property price compared to other kinds of railway stations [9].

The hedonic price model was applied to this research to find the property value because the land and property values were integrated $[40,41]$. The hedonic price is the model used to estimate the value of houses and goods or other related things that cannot separately sell in the market; also, the model can be used to measure the regular metric in urban economics that leads to standardisation for measuring the impact of HSR [41]. In Santander city, Spain, for instance, the result of investigations into a correlation between the number of transit lines and housing areas revealed an increase of $1.8 \%$ on housing prices in the HSR station area for each new line. In contrast, it was also found that the housing price decreased with an increase in travel time by a single minute [42].

Regarding the land use, changing or upgrading the land use type was associated with HSR services [43]. Nevertheless, the percentage increase brought on by changing models in a land cell was slight in the short term; therefore, the positive influences on the upgrade of land cells from HSR services might be excluded. Washington, D.C. was a role model for the management of accessibility in an area and showed excellent availability [27]. The city became rapidly developed, as it provided a cycle of journey and destination planning that encouraged people to travel using public transportation.

\subsection{Impact of the HSR on Relocation}

The potential transportation infrastructure is a crucial factor for households and firms in deciding to relocate due to the fact that a high-quality transportation system provides positive impacts on human life, i.e., increasing productivity, reducing travel costs in the city and enhancing business areas [5]. Some research found that the trend of moving the workplace to near the HSR station area was preferred [44]. However, a location near the HSR station was not the only factor that made people relocate, the urban development and economics of the area were also important. For example, people first choose a new place that is reasonably priced and has suitable accessibility; also, the city's economy is the primary reason for the choice. The study of migrating observations in Japan evaluated the change in population compared with the adjustments on HSR infrastructure. There was a sample of approximately 100 cities that represented the outcomes of the study. The results found that the 
population numbers and number of employees of the cities with HSR services were significantly higher than the cities without HSR services [45].

The relocation of the population could be separated into two areas, which are residential and workplaces. Regarding workplaces, they must be located nearby the city's business area, and the location relates to the density of the employment flow in the central business district [5]. The willingness of office relocations showed that people preferred a workplace nearby HSR stations [44,45]. In addition, the attractiveness of mercantile communities, which are located nearby HSR stations, has convinced people to visit due to the potential of accessibility. Both attractiveness and availability could indeed force a new economic zone. Concerning residential locations, people always select a place with options nearby, like residential convenience factors such as grocery stores, schools, and hospitals. Due to this household location theory, many utility factors have been composed with the household's location in mind, such as building price, public transit and the city's welfare. Moreover, there are many perspectives that define the best place of residence-for example, discrete choice models with characteristics of the housing market for maximising utility were employed in one study [46]. One of the assumptions in Friedman's model is choosing a location based on the maximum number of facility functions, i.e., employment areas, residential areas and safety.

\subsection{Population Dynamics}

Many publications revealed that HSR services mainly impact population change and employment rate in the city due to the service genuinely increasing the accessibility of areas. This study aimed to find the relationship between HSR services and population dynamics by using a statistical model based on long-term data collection.

Regarding the employment rate, people move into the business areas that are defined by higher income rates and more job opportunities [47]. Some researchers believe that the impact of population dynamics indeed comes from the city's economy and urbanisation characteristics [20,48], but some people believe that accessibility incites more changes in the population [49-52]. Research into population dynamics has also found that the population and employment rate were observed to have a higher growth rate due to HSR services [45]. In contrast, the potential accessibility had a substantial impact on population change, but it was not affected by the rail network in some countries such as in Finland [10]. However, the results of this study were obtained and discussed based on a commuter train network instead of HSR; also, the study took its data from a very small town where people mostly used their own cars.

Moreover, HSR has given the advantage of expanding job opportunities. Some research found that the services allow people to select long-distance workplaces without any concern for travel options because the services provide high accessibility and frequent services [53,54]. Another study analysed employment gains due to HSR in Korea by using three analysis functions; the Wright coefficient, the Gini coefficient, and the density function [55]. The results revealed that the HSR led to an increase in employment rate and the country's economy, as a result of expanding commercial areas.

One acceptable approach is to formulate regional jobs, i.e., rate the characteristics of the city, the percentage of accessibility, labour availability, etc.

$$
E_{r}=f\left(W_{r}, A_{c c}, L_{r} \ldots\right),
$$

where $E_{r}=$ effect of transport facilities, $\mathrm{W}_{\mathrm{r}}=$ wage rate, $\mathrm{Acc}_{\mathrm{r}}=$ accessibility and $\mathrm{LA}_{\mathrm{r}}=$ labour availability.

This approach has been applied to many pieces of research. In England, for instance, a study focused on the relationship between transportation factors (i.e., cost, service, accessibility) and employment factors (i.e., wages, job availability) [19]. Similarly, the model was applied with regression techniques to analyse regional employment in Britain during 1961-1966. The authors explained that the job availability was dispersed from the centre via the roads instead of the rail track. In another study in the North America urban area, the authors found that developing accessibility could increase 
the employment rate by up to twenty times. However, they believed that the development of regional reachability came from social work. Furthermore, the accessibility of the area impacted the growth of the whole region, in particular expanding the job opportunities. This case study was an excellent example of over prediction of the impacts of transportation on society [20,21].

Relative accessibility, another method, was applied to reduce the overestimation of the impact of HSR on the employment rate. The analysis showed that operating HSR services could have an impact on the jobs provided, but that the services might be included with other factors. Furthermore, some researchers pointed out that rural women gained greater benefits than men from transportation improvements. The removal of the job barrier for women could also lead to increasing wages [56]. In Scotland, the transportation system has changed people's routines. It instigated massive growth in the production process related to workers' requirements from manufacturers. However, it is important to note that North America and the UK do not have integrated HSR services and this understanding might be insufficient for fully integrated transport policies with respect to HSR services.

\section{Case Studies}

In this study, the HSR system in Shanghai is taken into account due to the fact that its network has grown up dramatically [57]. The HSR network in China has been denoted as the world's largest network with a total length of $35,000 \mathrm{~km}$ [58]. The network has had a massive impact on Chinese society in terms of land use, the labour force, economic and population change, especially in the decentralised big cities [59].

\section{Overview of HSR in Shanghai}

Shanghai city is the largest city in China, and had a population of 24.15 million in 2016. The average population density is 2059 people per square mile [60-62]. Shanghai is denoted as one of the business cities of China due to the fact that the city has shown dramatic annual growth in GDP and the number companies and workers. Regarding the transportation development in Shanghai, the government has invested in both public and inter-city transit in the city, an investment which is well known as the $8+8$ HSR grid project, linking Beijing and Shanghai.

The HSR service between Beijing-Shanghai has been operated by China Railways with the aims of connecting $23 \mathrm{big}$ cities across the country. The operation of the HSR can shorten travel time on service from $12 \mathrm{~h}$ to $5 \mathrm{~h}$. Based on this service, the total distance between the two cities is $1318 \mathrm{~km}$, and the train stops only at the main stations, including Tianjin, Taian, Jinan and Nanjing. The annual report mentioned that the average number of passengers was approximately 1.5 billion per year [62]. The service's outcomes provide benefits to workers who work and live between the two core cities and travelers, due to the fact that both Beijing and Shanghai are the most popular tourists' cities.

Considering the various travel modes between Shanghai and Beijing shown in Table 2, there are many alternative options to travel, including private car, regular train, HSR and airplane. The travelling option by airplane plays a distinctive role in terms of having the shortest travel time; however, the passengers must prepare to spend extra time at the airport for the security check, and for various contingencies that compromise travel time between the city centre and airports. Therefore, the average actual total travel time by airplane has been estimated to be at least $4.15 \mathrm{~h}$, which was close to the HSR service at $4.48 \mathrm{~h}$. In terms of the cost of travel, a standard train provides the lowest cost of travel from $\$ 21$ to $\$ 71$ depending on the class of service; whereas, the HSR offers the cost of travel at \$85-\$269 for a single trip. Moreover, a passenger can get a discount on advanced bookings. With respect to mobility by private car, this requires at least a $12 \mathrm{~h}$ journey; also, the fuel cost is estimated at $\$ 443$ (estimated in March 2020); nevertheless, the private car may be worth it if sharing the cost as a group or for family travel. 
Table 2. The comparison of the options for travel from Beijing to Shanghai via one-way trip in terms of total travel time and cost of transportation (calculated in March 2020) [63].

\begin{tabular}{cccccc}
\hline $\begin{array}{c}\text { Mode of } \\
\text { Transportation }\end{array}$ & $\begin{array}{c}\text { Average Speed } \\
\mathbf{( k m} / \mathbf{h})\end{array}$ & $\begin{array}{c}\text { Extra } \\
\text { Time (h) }\end{array}$ & $\begin{array}{c}\text { Total Time in the } \\
\text { Mode of } \\
\text { Transportations (h) }\end{array}$ & $\begin{array}{c}\text { Actual Total } \\
\text { Time (h) }\end{array}$ & $\begin{array}{c}\text { Cost of } \\
\text { Transportation } \\
\mathbf{( \$ )}\end{array}$ \\
\hline Private car & Vary & 0 & 13 & 13 & $\$ 443$ (per car) \\
Standard train & $80-120$ (non-fixed) & 0 & $14-22$ & $14-22$ & $\$ 21-\$ 71$ \\
HSR & 350 & 0 & $4.48-6.12$ & $4.48-6.12$ & $\$ 85-\$ 269$ \\
Airplane & $880-920$ & 2 & 2.15 & 4.15 & $\$ 369$ (Average) \\
\hline
\end{tabular}

Regarding the local travel within Shanghai city, the Beijing-Shanghai HSR service stops at the Shanghai Hongqiao station, which is the main transportation hub of the city. The transportation hub includes taxi, bus and metro services in the city, intercity HSR lines and standard train services $[64,65]$. The hub provides convenient connections for a passenger to travel using public transportation; also, it has encouraged investors and businesses to invest in Shanghai. The outcome of the excellent planning of city transportation has provided invaluable benefits to the city's income and urbanisation.

\section{Data Collection and Data Analysis}

Based on the literature review, HSR networks have an impact on population dynamics and land price in many countries $[1,26,29-31,33,34]$. The achievement of HSR networks leads to socio-economic developments. This study aims to find the correlation between HSR services and socio-economic development in China. Therefore, two selected variables have been taken into account on the analysis stage, including the population and the land price. The research framework is shown in Figure 2.

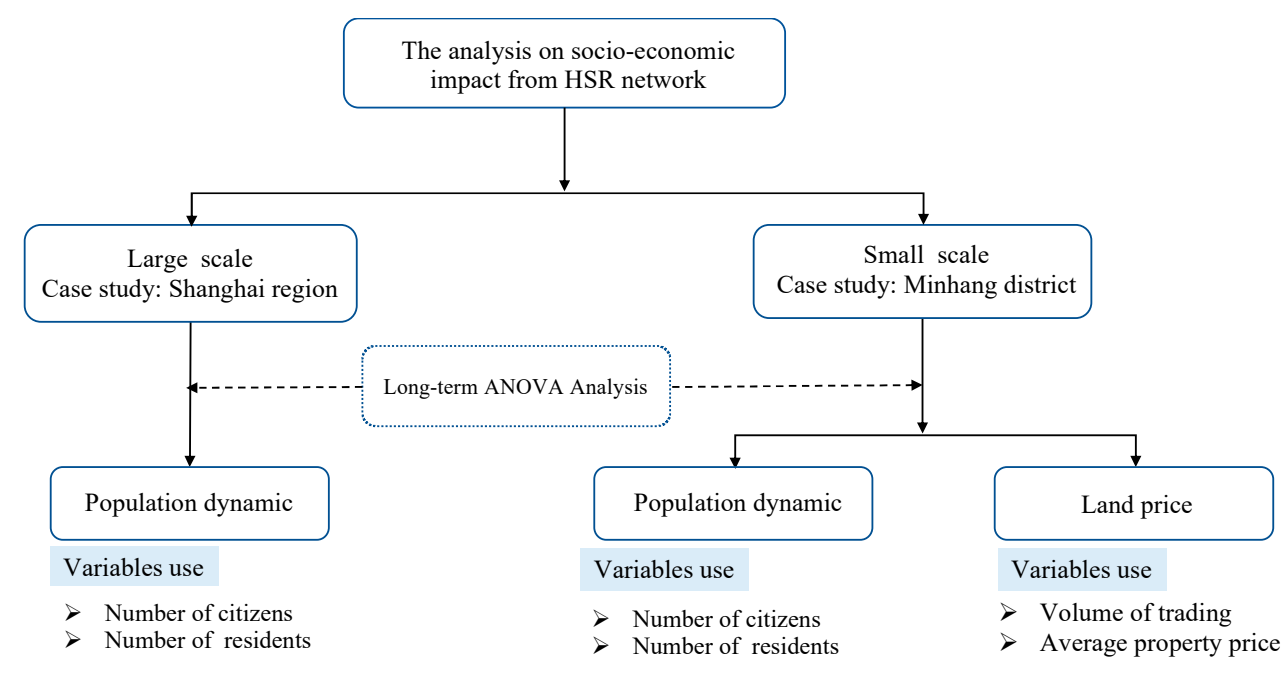

Figure 2. The research framework.

\subsection{Data Collection on the Population Dynamics}

The study has gathered the data on residential dwelling and citizenship in Shanghai city from 1990 to 2017. The term resident applies to people who are working and staying in Shanghai, but who are not registered as a citizen, including immigrants; however, citizenship applies to people who are registered and currently staying in Shanghai $[66,67]$.

In Table 3, the number of residents has increased dramatically by nearly double in 28 years from 13.34 million to 24.18 million, but the number of citizens has risen by approximately 1 million. This can be explained by the fact that people usually visit Shanghai city for work or temporary stays. The characteristic of the high volume of residents can be explained by the urban agglomeration that usually occurs in commercial areas in big cities such as Jakarta, Moscow, London, New York, Berlin and 
Paris [68]. There are many contributing factors towards the expansion of the city, i.e., low transportation cost, big labour markets, and highly specialised service sectors. Related to the transportation factors, the high capacity of transportation hubs, high quality of infrastructure, and good layout of the public transportation system are key driving factors for a business city.

Table 3. The summary of residents and citizens in Shanghai (unit: million).

\begin{tabular}{cccccc}
\hline Year & Residents & Citizens & Year & Residents & Citizens \\
\hline 1990 & 13.34 & 12.83 & 2004 & 18.35 & 13.52 \\
1991 & 13.50 & 12.87 & 2005 & 18.90 & 13.60 \\
1992 & 13.65 & 12.89 & 2006 & 19.64 & 13.68 \\
1993 & 13.81 & 12.95 & 2007 & 20.64 & 13.79 \\
1994 & 13.98 & 12.99 & 2008 & 21.41 & 13.91 \\
1995 & 14.14 & 13.01 & 2009 & 22.10 & 14.01 \\
1996 & 14.51 & 13.04 & 2010 & 23.03 & 14.12 \\
1997 & 14.89 & 13.05 & 2011 & 23.47 & 14.19 \\
1998 & 15.27 & 13.07 & 2012 & 23.80 & 14.27 \\
1999 & 15.67 & 13.13 & 2013 & 24.15 & 14.32 \\
2000 & 16.09 & 13.22 & 2014 & 24.26 & 14.39 \\
2001 & 16.68 & 13.27 & 2015 & 24.15 & 14.35 \\
2002 & 17.13 & 13.34 & 2016 & 24.20 & 14.38 \\
2003 & 17.66 & 13.42 & 2017 & 24.18 & 14.39 \\
\hline
\end{tabular}

\subsection{Data Analysis of the Population Dynamics in Shanghai}

As part of the analysis of population dynamics, the relocation of the population reflects people's reactions, attitudes, and behaviours towards the HSR services. As mentioned in Section 3, this research embarks on an ANOVA analysis using Equations (1) and (2). Next, the Durbin-Watson statistical analysis, which is usually used with a time-series data set, is applied to the collected data on population dynamics in Shanghai during 1990-2017. The Durbin-Watson statistical formula can be written as Equation (4).

$$
d=\frac{\sum\left(e_{t}-e_{t-1}\right)^{2}}{\sum e_{t}^{2}}
$$

where $\mathrm{d}=$ the value of the Durbin-Watson statistic and $e_{t}=$ the error term of $\mathrm{t}(\mathrm{t}=1,2, \ldots, \mathrm{n})$.

The analysis results of the Durbin-Watson statistic on the population dynamics exhibit the values of residents and citizens at 0.264 and 0.293 , respectively. After comparing with the standard Durbin-Watson table [69], this shows autocorrelation in both resident and citizen values. Therefore, the remedial measurement can be further applied to this analysis in order to eliminate the autocorrelation in this analysis.

The results of remedial measurements on residence and citizenship represent the dummy variables of residence and citizenship at -0.186 and -0.024 , respectively, whereas the T-statistic values are -1.340 and -1.199 , respectively, as shown in Table 4. The analysis results can infer that HSR has no significant impact on the population dynamics in Shanghai during 1990-2017; in other words, the change in population might occur from other factors such as jobs, city attractions, and urban sprawl.

Table 4. Remedial measurement of residents and citizens.

\begin{tabular}{|c|c|c|c|c|}
\hline Dependent Variable & Residents & & Citizens & \\
\hline \multirow{4}{*}{$\begin{array}{c}\text { Dummy variable } \\
\text { T-statistic }\end{array}$} & -0.186 & & -0.024 & \\
\hline & $(-1.340)$ & & $(-1.199)$ & \\
\hline & F-statistic & 3595.1 & F-statistic & 3477.5 \\
\hline & Durbin-Watson statistic & 1.943 & Durbin-Watson statistic & 1.945 \\
\hline
\end{tabular}




\subsection{Data Analysis on the Population Dynamics and Land Price in Minhang}

The analysis results for the Shanghai region in Section 6.2 reveal that the HSR services have no significant impact on the population dynamics. Therefore, this study further conducts data fusion with data from Minhang city, which is a suburban district in Shanghai, to deeply focus on a specific area since the Minhang district is the terminal station of the HSR service in the Shanghai region. This research gathers the data from 2005 to 2017 in terms of citizenship, residents, the volume of trading and the average property price $[66,67]$.

The volume of trading and the average property price variables can measure the impact of HSR services on land price, whereas the number of citizens and residents can reflect population dynamics after the advent of the HSR service. Those factors can lead to the rational justification of socio-economic development within a suburban area.

Moreover, first-order regression analysis models have been established in order to predict the number of citizens, property prices, number of residents, and volume of trade. The datasets between 2005 and 2017 are collected as tabulated in Table 5 and used to predict the extrapolated population dynamic parameters from 2018 to 2025, as shown in Figure 3.

Table 5. Summary of the average volume of trading, average property price, citizens and residents in Minhang district.

\begin{tabular}{ccccc}
\hline Year & $\begin{array}{c}\text { Volume of Trading } \\
\left(\mathbf{m}^{\mathbf{2}}\right)\end{array}$ & $\begin{array}{c}\text { Average Property Price } \\
\left(\mathbf{C N Y} / \mathbf{m}^{\mathbf{2}}\right)\end{array}$ & $\begin{array}{c}\text { Citizenship } \\
(\text { Million })\end{array}$ & $\begin{array}{c}\text { Residence } \\
(\text { Million})\end{array}$ \\
\hline 2005 & $2,973,400$ & 9873 & 0.83 & 1.71 \\
2006 & $2,654,400$ & 10,477 & 0.86 & 1.83 \\
2007 & $2,860,300$ & 11,246 & 0.86 & 1.86 \\
2008 & $1,200,300$ & 16,383 & 0.92 & 1.8 \\
2009 & $2,417,700$ & 16,533 & 0.94 & 1.83 \\
2010 & 837,900 & 23,118 & 0.97 & 2.43 \\
2011 & 440,900 & 27,496 & 0.98 & 2.48 \\
2012 & 587,300 & 27,411 & 1.00 & 2.5 \\
2013 & 833,700 & 29,460 & 1.02 & 2.53 \\
2014 & 632,000 & 35,771 & 1.05 & 2.54 \\
2015 & $1,116,900$ & 39,908 & 1.07 & 2.56 \\
2016 & $1,141,170$ & 41,007 & 1.10 & 2.59 \\
2017 & $1,280,840$ & 44,089 & 1.12 & 2.61 \\
2018 & $1,420,510$ & 47,171 & 1.15 & 2.64 \\
2019 & $1,560,180$ & 50,253 & 1.17 & 2.67 \\
2020 & $1,699,850$ & 53,335 & 1.19 & 2.70 \\
2021 & $1,839,520$ & 56,417 & 1.22 & 2.72 \\
2022 & $1,979,190$ & 59,499 & 1.24 & 2.74 \\
2023 & $2,118,860$ & 62,581 & 1.27 & 2.76 \\
2024 & $2,258,530$ & 65,662 & 1.29 & 2.79 \\
2025 & $2,398,200$ & 68,744 & 1.31 & 2.81 \\
\hline
\end{tabular}

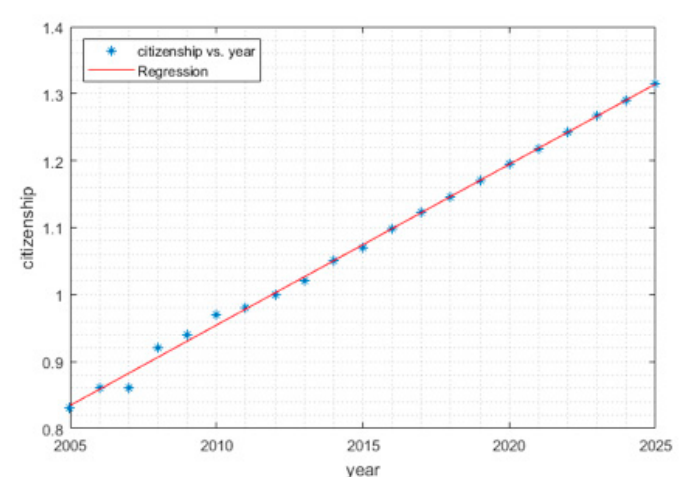

(a)

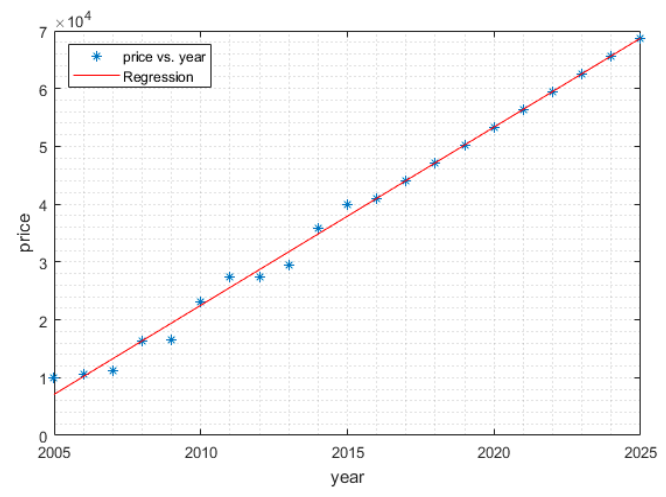

(b)

Figure 3. Cont. 


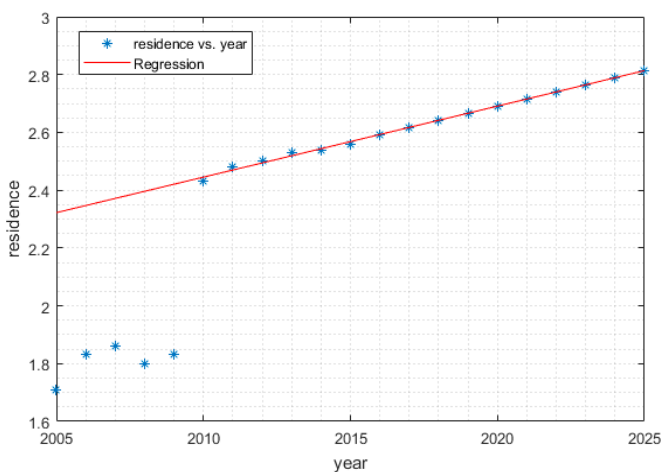

(c)

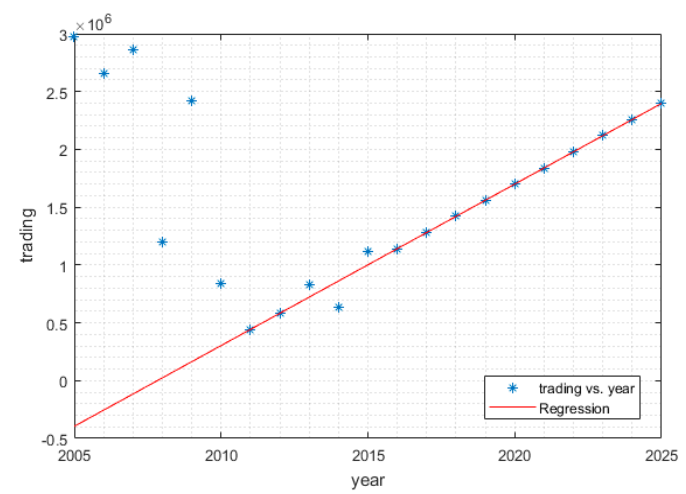

(d)

Figure 3. The first-order polynomial regression analysis models of (a) citizenship, (b) average property price, (c) residents and (d) volume of trading.

\subsection{Data Analysis Result on the Population Dynamics in Minhang}

The initial data analyses show that the land price in China is not related to any factor, including the HSR services. This is attributed to the fact that the value of land price in China has been strictly controlled by the government. However, it is evident that the trading value of land use (or the cost of space utility) is directly affected by agglomeration and urbanisation, which is also continually influenced by the HSR services.

In Table 6, the analysis of citizenship data in the Minhang district points out that the Durbin-Watson statistic value is 0.9273 (including autocorrelation values). Then, the Durbin-Watson statistic shows a value of 1.6786 based on the remedial measurement analysis. It can be hinted that HSR services have certainly enabled a small impact on the number of citizens in the Minhang city.

Table 6. An analysis of citizenship.

\begin{tabular}{llll}
\hline $\begin{array}{l}\text { Dependent Variable: Citizenship } \\
\text { Regression a }\end{array}$ & & Remedial Measure & \\
\hline C & $898.618^{\text {a }}$ & C & $1417.981^{\text {a }}$ \\
& $(48.349)$ & & $(10.399)$ \\
Dummy & $124.710^{\text {a }}$ & Dummy & -6.481398 \\
& $(4.524)$ & & $(-1.795)$ \\
& & AR (1) & $0.947568^{\text {a }}$ \\
& & & $(63.914)$ \\
R-squared & 0.6945 & R-squared & 0.998195 \\
Adjusted R-squared & 0.6606 & Adjusted R-squared & 0.997679 \\
S.E. of regression & 45.5263 & S.E. of regression & 3.308817 \\
F-statistic & 20.4646 & F-statistic & 1935.701 \\
Prob. (F-statistic) & 0.0014 & Prob. (F-statistic) & 0.0000 \\
Durbin-Watson statistic & 0.9273 & Durbin-Watson statistic & 1.6786 \\
\hline
\end{tabular}

${ }^{a}$ represent significant of HSR at $10 \%$ level.

In addition, the analysis of residents in Minhang district shows a regression value of 5.209, which infers that HSR services have a more significant impact on resident numbers in this district than other areas, as shows in Table 7. On the other hand, this provides evidence that HSR services have also played a bigger role in the workflow in the city, business areas and investors than in residential purposes. 
Table 7. An analysis of residents.

\begin{tabular}{ll}
\hline $\begin{array}{l}\text { Dependent Variable: Residents } \\
\text { Regression }\end{array}$ \\
\hline $\mathrm{C}$ & 1908.05 \\
& $(23.894)$ \\
Dummy & 616.95 \\
& $(5.209)$ \\
R-squared & 0.7509 \\
Adjusted R-squared & 0.7232 \\
S.E. of regression & 195.6057 \\
F-statistic & 27.1310 \\
Prob. (F-statistic) & 0.0006 \\
Durbin-Watson statistic & 2.0124 \\
\hline
\end{tabular}

Analogously, the analysis of the property price reveals a Durbin-Watson value of 1.1844. As a result, a remedial measurement can be applied to reduce the autocorrelation error. The dummy variable has been determined to be 0.505 , and the Durbin-Watson statistic value is 2.2720 , as shown in Table 8 . It can be interpreted that there is no significant contribution to the property price from HSR services in the Minhang district.

Table 8. An analysis of property price.

\begin{tabular}{llll}
\hline $\begin{array}{l}\text { Dependent Variable: Property Price } \\
\text { Regression a }^{\text {a }}\end{array}$ & Remedial Measure \\
\hline C & $\begin{array}{lll}14,605^{\mathbf{a}} \\
(6.726)\end{array}$ & $\mathrm{C}$ & $\begin{array}{l}474,036^{\mathbf{a}} \\
(0.056)\end{array}$ \\
Dummy & $17,404.2^{\mathbf{a}}$ & Dummy & 1568.144 \\
& & & $(0.505)$ \\
& & AR (1) & $0.994^{\mathbf{a}}$ \\
& & & $(8.546)$ \\
R-squared & 0.7644 & R-squared & 0.9345 \\
Adjusted R-squared & 0.7382 & Adjusted R-squared & 0.9157 \\
S.E. of regression & 5318.9150 & S.E. of regression & 2910.5280 \\
F-statistic & 29.2005 & F-statistic & 49.9103 \\
Prob. (F-statistic) & 0.0004 & Prob. (F-statistic) & 0.0001 \\
Durbin-Watson statistic & 1.1844 & Durbin-Watson statistic & 2.2720 \\
\hline
\end{tabular}

${ }^{a}$ represent significant of HSR at $10 \%$ level.

Figure 4 illustrates the trend of average property price in Shanghai (yellow line) and Hongqiao (blue line) from 2005 to 2015. The Hongqiao sub-district locates within the Minhang district of Shanghai province. The Hongqiao area is well known as the major transportation hub, including an HSR network, inter-city HSR, buses, taxis and other modes of transport. Before 2010, the growth rate of the property price between Shanghai and Hongqiao seemed to be similar. The rise in the property prices could be affected by both cities' economic growth, local demand and supply of the residential assets. It is clear that, since 2010, the opening of the Hongqiao transportation hub has profoundly impacted the property demand in the surrounding area of the transportation hub. As a result, the gap between the property prices in Shanghai and Hongqiao has become significantly apparent. It can be observed that the demand for buildings near the Hongqiao transportation hub has been remarkably increased, owing to people's desire to reach HSR services within a reasonable distance. However, there are other potential factors related to the property price, including inflation rate, location and country's economy. This issue will be discussed later in Section 7. 


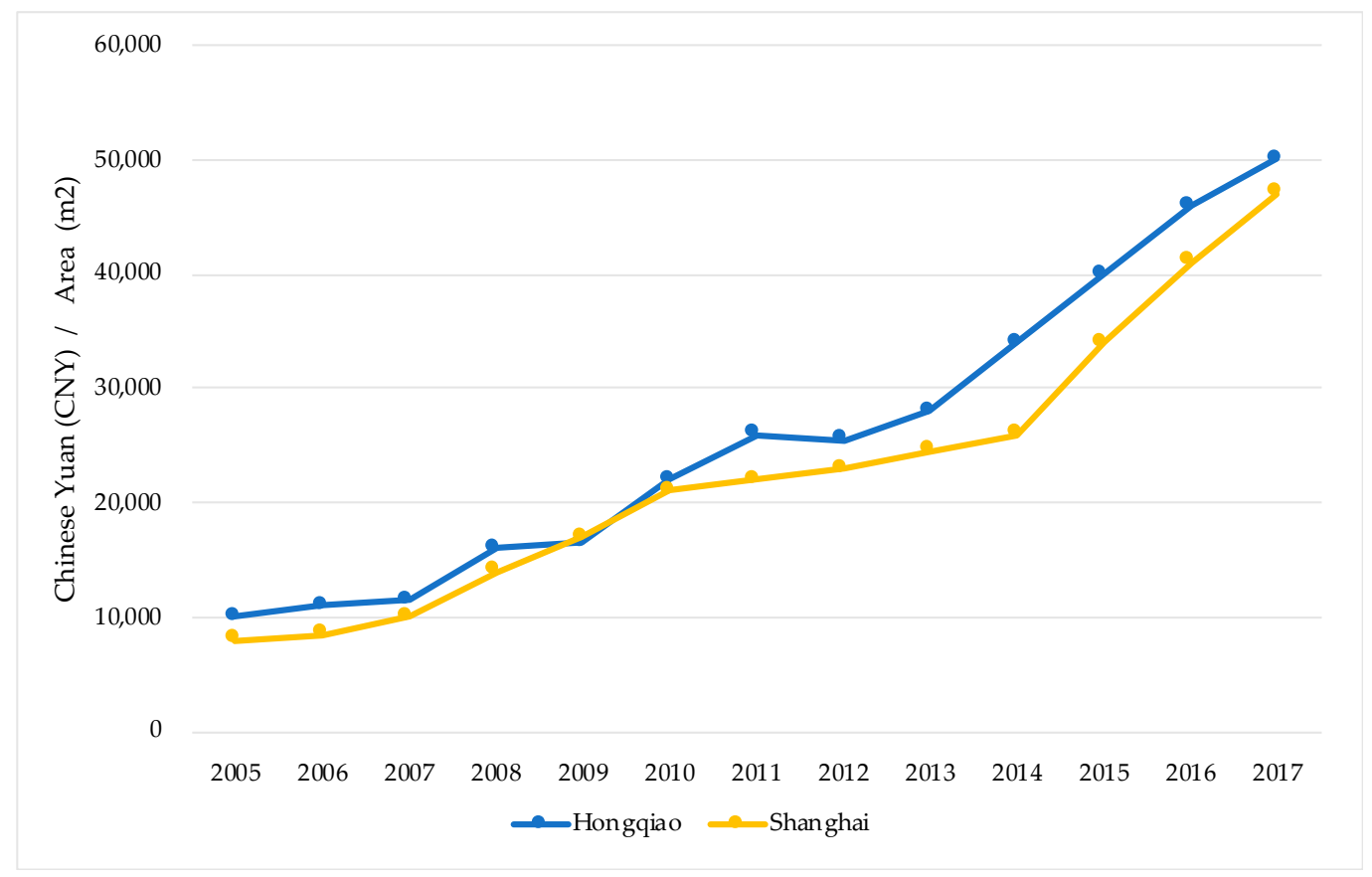

Figure 4. The comparison between property prices in the Hongqiao district and the overall Shanghai region.

\section{Discussion}

With the aim of studying the socio-economic impact of HSR, the result for population dynamics has shown that HSR had more of an impact on the Minhang district than the Shanghai region. The study has also found that the station in Minhang district has served more passengers than the station in Shanghai province since the Minhang district is the terminal station of the HSR line. Another result has revealed that only around 100,000 passengers utilised the terminal station, but 24.15 million residents lived in Shanghai during that time. The vast difference between the numbers of HSR passengers and local residents reflects that the HSR services had a low impact on population dynamics in the Shanghai region.

It is found that the spatial structural characteristics of Shanghai are barriers that cause a low impact by HSR services. Shanghai is one of the largest cities in China and the region contains more than 200 cities. The city area is about $6300 \mathrm{~km}^{2}$, but the city centre area (or business district) is only 5-6 $\mathrm{km}$ in radius [43]. Hence, it is clear that the HSR services have a bigger impact on a smaller scale, as in the Minhang district, than a large scale, as in the Shanghai region.

With respect to this study, the investigations have been based on the long-term data of the population dynamics and land price. The analysis results have also pointed out that the HSRs have offered a small impact on population dynamics and land price in Minhang city and Shanghai province. In addition, the prediction results from this study have demonstrated that the HSR will not significantly influence the land price and the population dynamics until 2025.

\section{Research Recommendations}

This study has carried out a profound analysis on the socio-economic impact of the HSR network by using long-term data from China. The outcome indicates that HSR services have provided a low impact on the population dynamics and land price in China. In addition, HSR has had a small effect on urban dynamics around the terminal station in Minhang district.

As demonstrated in the analysis results, the impact of HSR services on society in China is insignificant. The finding is different from other HSR networks around the world. For example, the Shinkansen network has a considerable impact on the prefecture land price and the growth of 
population. In addition, it has enabled various benefits for Japanese life. The Shinkansen connection can reduce the land price by $33 \%$ within the same year, as its services can support Japan in becoming decentralised [68]. In France, another case study showed that the land price was found to be increased by around $2.18 \%$ compared to the average in the area due to the TGV service [69]. However, the results of this study are rather conclusive that HSR servies have little impact in China's experience. The finding is supported by the fact that the land price has been strictly controlled by the government for various purposes [70-73]; therefore, the HSR service has not affected the key urbanisation factors.

With respect to the aspects of sustainable development systems thinking on HSR services [74-76], the efficient planning of HSR services can genuinely generate invaluable outcomes for other social, economic and environmental impacts [77,78], as follows:

- $\quad$ Social impacts: reducing travel time between two cities, increasing the accessibility of attractions in the city, reducing the public transportation cost, allowing companies to hire specific labourers and trade in particular goods;

- Economic impacts: increasing the economic via the transport and the logistic system (both domestic and international), immediately transferring products from the suburban areas, reducing shipping costs in the country as there is an alternative mode of transportation;

- Environmental impacts: reducing the amount of $\mathrm{CO}_{2}$ emissions in the air, reducing the amount of land use compared with the road and highway.

\section{Conclusions}

With respect to the aim of investigating the impact of HSR services on the socio-economic parameters in China, relevant data has been collected from Minhang city and Shanghai province. Predictions for the volume of trading $\left(\mathrm{m}^{2}\right)$, property price, citizenship and residence are established in order to project the trend up until 2025. The outcomes will be genuinely beneficial to the HSR operators and policymakers in planning the services in future.

Regarding the population dynamics, this study has demonstrated that HSR services play an insignificant role in the urbanisation of the Shanghai region, but HSR did show a certain degree of influence on a smaller scale in the Minhang district. The trends are similar to the effect of HSR services on the land price, whereas the land use's trade price has increased slightly within a $5 \mathrm{~km}$ radius of the transport hub in a smaller city. The main reasons for these findings are that:

(i) The socio-economic factors may relate to other factors, i.e., the location of the city, the type of train in service and the country's GDP;

(ii) The characteristics of the region are the key contributors towards the success of HSR services; thus, to enable viable sustainable development, HSR services should cooperate with the city's policymakers, business groups and related experts, who can enable the full integration of HSR services with urban planning, societal values, and other externalities.

Author Contributions: S.K. provided ideas and suggestions regarding this study and also gave final approval of the version to be submitted and any revised versions. The predictive analysis section and data correction were both provided by P.R., in order to ensure that the article was up-to-date and suitably applied to the current HSR development stage. Moreover, Y.Y. collected the data and provided the literature and analysis models. All authors participated in writing the article. All authors have read and agreed to the published version of the manuscript.

Funding: This research was funded by European Commission for the financial sponsorship of the H2020-MSCA-RISE Project No. 691135 “RISEN: Rail Infrastructure Systems Engineering Network," which enables a global research network that tackles the grand challenges of railway infrastructure resilience and advanced sensing.

Acknowledgments: The first author gratefully appreciates the Royal Thai Government for her PhD scholarship. The corresponding author is grateful to the Australian Academy of Science (AAS) and Japan Society for the Promotion of Sciences (JSPS) for his JSPS Invitation Fellowship for Research (Long-term), Grant No. JSPS-L15701, at Railway Technical Research Institute (RTRI) and the University of Tokyo, Japan. The authors are sincerely grateful to the European Commission for the financial sponsorship of the H2020-MSCA-RISE Project No. 691135 
“RISEN: Rail Infrastructure Systems Engineering Network," which enables a global research network that tackles the grand challenges of railway infrastructure resilience and advanced sensing.

Conflicts of Interest: The authors declare no conflict of interest.

\section{References}

1. Tetsuya, H.; Yano, T.; Murakami, Y. Annoyance due to railway noise before and after the opening of the Kyushu Shinkansen Line. Appl. Acoust. 2017, 115, 173-180. [CrossRef]

2. Gallego, J.A.G.; Gómez, J.M.N.; Cabanillas, F.J.J.; Labrador, E.E.R.; Jeong, J.S. A methodology to assess the connectivity caused by a transportation infrastructure: Application to the high-speed rail in Extremadura. Case Stud. Transp. Policy 2015, 3, 392-401. [CrossRef]

3. Kojima, Y.; Matsunaga, T.; Yamaguchi, S. The impact of new Shinkansen lines (Tohoku Shinkansen) (Hachinohe-Shin-Aomori) and Kyusyu Shinkansen (Hakata-Shin-Yatsushiro)). Transp. Res. Procedia 2017, 25, 344-357. [CrossRef]

4. Chen, X.; Lin, L. The Integration of Air and Rail Technologies: Shanghai's Hongqiao Integrated Transport Hub. J. Urban Technol. 2016, 23, 23-46. [CrossRef]

5. $\mathrm{Xu}, \mathrm{W}$; Huang, Y. The correlation between HSR construction and economic development-Empirical study of Chinese cities. Transp. Res. Part A Policy Pract. 2019, 126, 24-36.

6. Guiliano, G.; Chakrabarti, S.; Rhoads, M. Transport and Urban Spatial Structure Are Interdependent. In International Encyclopedia of the Social \& Behavioral Science, 2nd ed.; Elsevier: Oxford, UK, 2015.

7. Pan, H.; Zhang, M. Rail Transit Impacts on Land Use: Evidence from Shanghai, China. Transp. Res. Rec. J. Transp. Res. Board 2008, 2048, 16-25. [CrossRef]

8. Mohammad, S.I.; Graham, D.J.; Melo, P.; Anderson, R.J. A meta-analysis of the impact of rail projects on land and property values. Transp. Res. Part A Policy Pract. 2013, 50, 158-170. [CrossRef]

9. Debrezion, G.; Pels, E.; Rietveld, P. The impact of railway stations on residential and commercial property value: A Meta-analysis. J. Real Estate Financ. Econ. 2007, 35, 161-180. [CrossRef]

10. Boulton, C.; Dedekorkut-Howes, A.; Byrne, J. Factors shaping urban greenspace provision: A systematic review of the literature. Landsc. Urban Plan. 2018, 178, 82-101. [CrossRef]

11. Knowles, R.D.; Ferbrache, F. Evaluation of wider economic impacts of light rail investment on cities. J. Transp. Geogr. 2016, 54, 430-439. [CrossRef]

12. Blanquart, C.; Koning, M. The local economic impacts of high-speed railways: Theories and facts. Eur. Transp. Res. Rev. 2017, 9, 12. [CrossRef]

13. UIC. High-Speed Rail—Fast Track to Sustainable Mobility. 2019. Available online: https://uic.org/highspeed (accessed on 16 February 2019).

14. Global Economic Prospects—Slow Growth, Policy Challenges; The World Bank Group: Washington, DC, USA, 2019.

15. Ollivier, G.; Bullock, R.; Ying, J.; Zhou, N. High-Speed Railways in China: A Look at Traffic, China Transport Topics. 2014, pp. 1-12. Available online: http://www-wds.worldbank.org/ external/default/WDSContentServer/WDSP/IB/2014/12/16/000406484_20141216102415/Rendered/PDF/ 932270BRI0Box30ffic020140final000EN.pdf (accessed on 28 January 2020).

16. The World Bank. Regional Economic Impact Analysis of High-Speed Rail in China; Report No.ACS9734, Main Report; World Bank Group: Washington, DC, USA, 2014.

17. Chang, Y.; Lei, S.; Teng, J.; Zhang, J.; Zhang, L.; Xu, X. The energy use and environmental emissions of high-speed rail transportation in China: A bottom-up modeling. Energy 2019, 182, 1193-1201. [CrossRef]

18. Wang, L. High-speed rail services development and regional accessibility restructuring in megaregions: A case of the Yangtze River Delta, China. Transp. Policy 2018, 72, 34-44. [CrossRef]

19. Chen, G.; Silva, J.D.A.E. Using Dynamic Simultaneous-equation Model to Estimate the Regional Impacts of High-speed Rail in Spain. Transp. Res. Procedia 2015, 10, 296-305. [CrossRef]

20. Graham, D.J. Agglomeration, productivity and transport investment. J. Transp. Econ. Policy 2007, 41, $317-343$. [CrossRef]

21. Popova, Y. Relations between Wellbeing and Transport Infrastructure of the Country. Procedia Eng. 2017, 178, 579-588. [CrossRef] 
22. Gutiérrez, J.; Condeço-Melhorado, A.; Martin, J.C. Using accessibility indicators and GIS to assess spatial spillovers of transport infrastructure investment. J. Transp. Geogr. 2010, 18, 141-152. [CrossRef]

23. Inturri, G.; Ignaccolo, M.; Le Pira, M.; Caprì, S.; Giuffrida, N. Influence of Accessibility, Land Use and Transport Policies on the Transport Energy Dependence of a City. Transp. Res. Procedia 2017, 25, 3273-3285. [CrossRef]

24. Chen, G.; Silva, J.D.A.E. Regional impacts of high-speed rail: A review of methods and models. Transp. Lett. 2013, 5, 131-143. [CrossRef]

25. Liu, R.; Chen, Y.; Wu, J.; Xu, T.; Gao, L.; Zhao, X. Mapping spatial accessibility of public transportation network in an urban area-A case study of Shanghai Hongqiao Transportation Hub. Transp. Res. Part D Transp. Environ. 2018, 59, 478-495. [CrossRef]

26. Shen, Y.; Silva, J.D.A.E.; Martínez, L.M. HSR Station Location Choice and its Local Land Use Impacts on Small Cities: A Case Study of Aveiro, Portugal. Procedia Soc. Behav. Sci. 2014, 111, 470-479. [CrossRef]

27. Xu, W.; Yang, L. Evaluating the urban land use plan with transit accessibility. Sustain. Cities Soc. 2019, 45, 474-485. [CrossRef]

28. Romão, J.; Neuts, B. Territorial capital, smart tourism specialization and sustainable regional development: Experiences from Europe. Habitat Int. 2017, 68, 64-74. [CrossRef]

29. Shen, Q. Location characteristics of inner-city neighborhoods and employment accessibility of low-wage workers. Environ. Plan. B Plan. Des. 1998, 25, 345-365. [CrossRef]

30. Van Wee, B.; Hagoort, M.; Annema, J.A. Accessibility measures with competition. J. Transp. Geogr. 2001, 9, 199-208. [CrossRef]

31. Joseph, A.E.; Bantock, P.R. Measuring potential physical accessibility to general practitioners in rural areas: A method and case study. Soc. Sci. Med. 1982, 16, 85-90. [CrossRef]

32. Bi, L.; Fan, Y.; Gao, M.; Lee, C.L.; Yin, G. Spatial mismatch, enclave effects and employment outcomes for rural migrant workers: Empirical evidence from Yunnan Province, China. Habitat Int. 2019, 86, 48-60. [CrossRef]

33. Wilson, A.G. A Family of Spatial Interaction Models, and Associated Developments. Environ. Plan. A Econ. Space 1971, 3, 1-32. [CrossRef]

34. Xu, W.; Zhou, J.; Yang, L.; Li, L. The implications of high-speed rail for Chinese cities: Connectivity and accessibility. Transp. Res. Part A Policy Pract. 2018, 116, 308-326.

35. Hägerstraand, T. What about people in regional science? Pap. Reg. Sci. 2005, 24, 7-24. [CrossRef]

36. Kitamura, R. Applications of models of activity behavior for activity-based demand forecasting. In Proceedings of the Activity-Based Travel Forecasting Conference, New Orleans, LA, USA, 2-5 June 1996.

37. Kwan, M.-P. Space-Time and Integral Measures of Individual Accessibility: A Comparative Analysis Using a Point-based Framework. Geogr. Anal. 2010, 30, 191-216. [CrossRef]

38. Ben-Akiva, M.; Lerman, S.R. Discrete Choice Analysis: Theory and Application to Travel Demand; The MIT Press: Cambridge, MA, USA, 1985.

39. Debrezion, G.; Pels, E.A.; Rietveld, P. The impact of rail transport on real estate prices: An empirical analysis of the Dutch housing market. Urban Stud. 2010, 48, 997-1015. [CrossRef]

40. Keeble, D.; Owens, P.L.; Thompson, C. Regional accessibility and economic potential in the European community. Reg. Stud. 1982, 16, 419-432. [CrossRef]

41. Zietz, J.; Zietz, E.N.; Sirmans, G.S. Determinants of House Prices: A Quantile Regression Approach. J. Real Estate Finance Econ. 2007, 37, 317-333. [CrossRef]

42. Zhuge, C.; Shao, C.; Gao, J.; Dong, C.; Zhang, H. Agent-based joint model of residential location choice and real estate price for land use and transport model. Comput. Environ. Urban Syst. 2016, 57, 93-105. [CrossRef]

43. Shen, Y.; Martinez, L.; Silva, J.D.A.E. Impacts of Short-Term Land Use by High-Speed Rail on Large Metropolises. Transp. Res. Rec. J. Transp. Res. Board 2013, 2374, 35-43. [CrossRef]

44. Willigers, J.; Van Wee, B. High-speed rail and office location choices. A stated choice experiment for the Netherlands. J. Transp. Geogr. 2011, 19, 745-754. [CrossRef]

45. Ohta, K. The development of Japanese transportation policies in the context of regional development. Transp. Res. Part A Gen. 1989, 23, 91-101. [CrossRef]

46. Quigley, J.M. Housing demand in the short-run: An analysis of polytomous choice. Explor. Econ. Res. 1976, 3, 76-102. 
47. Glaeser, E. The new economics of urban and regional growth. In The Oxford Handbook of Economic Geography; Oxford University Press: Oxford, UK, 2000; pp. 83-98.

48. Biehl, D. The role of infrastructure in regional development. In Infrastructure and Regional Development; Vickerman, R.W., Ed.; Pion: London, UK, 1991; pp. 9-35.

49. Rietveld, P.; Nijkamp, P. Transport and regional development. In European Transport Economics; Polak, J., Heertje, A., Eds.; Blackwell: Oxford, UK, 1993; pp. 130-151.

50. Wegener, M.; Bökemann, D. The SASI Model; SASI deliverable D8 report to the European Commission; European Union: Brussels, Belgium, 1998; p. 58.

51. Quinet, E.; Vickerman, R. Principles of Transport Economics; Edward Elgar Publishing: Cheltenham, UK, 2004; p. 385.

52. Moya-Gómez, B.; Salas-Olmedo, M.H.; García-Palomares, J.C.; Gutiérrez, J. Dynamic Accessibility using Big Data: The Role of the Changing Conditions of Network Congestion and Destination Attractiveness. Netw. Spat. Econ. 2018, 18, 273-290. [CrossRef]

53. Vermal, A.; Sudhira, H.S.; Rathi, S.; King, R.; Dash, N. Sustainable urbanization using high speed rail (HSR) in Karnataka, India. Res. Transp. Econ. 2013, 38, 67-77. [CrossRef]

54. Cascetta, E.; Coppola, P. High Speed Rail (HSR) Induced Demand Models. Procedia Soc. Behav. Sci. 2014, 111, 147-156. [CrossRef]

55. Kim, J.; Jargowsky, P.A. The GINI coefficient and segregation on a continuous variable. In Occupational and Residential Segregation; Flückiger, Y., Reardon, S.F., Silber, J., Eds.; Research on Economic Inequality; Emerald Group Publishing Limited: Bingley, UK, 2000; Volume 17, pp. 57-70.

56. MacDonald, H.; Peter, A.H. Distance and Labor Force Participations for Urban and Rural Women. In Urban Policy and the Census; Esri Press: Redlands, CA, USA, 2011; ISBN 158948222.

57. Huang, Y.; Lu, S.; Yang, X.; Zhao, Z. Exploring Railway Network Dynamics in China from 2008 to 2017. ISPRS Int. J. Geo-Inf. 2018, 7, 320. [CrossRef]

58. Chi, Z.; Lin, J.; Chen, R.; Huang, S. Data-driven approach to study the polygonization of high-speed railway train wheel-sets using field data of China's HSR train. Measurement 2020, 149, 107022. [CrossRef]

59. Hipgrave, D.B.; Guo, S.; Mu, Y.; Guo, Y.; Yan, F.; Scherpbier, R.; Brixi, H. Chinese-Style Decentralization and Health System Reform. PLoS Med. 2012, 9, e1001337. [CrossRef]

60. World Population Review Shanghai Population. 2019. Available online: http://worldpopulationreview.com/ world-cities/shanghai-population/ (accessed on 28 January 2020).

61. Ma, W.; Wang, Q.; Yang, H.; Zhang, A.; Zhang, Y. Effects of Beijing-Shanghai high-speed rail on air travel: Passenger types, airline groups and tacit collusion. Res. Transp. Econ. 2019, 74, 64-76. [CrossRef]

62. China Railway Construction Corporation Limited (CRCC). Annual Report. 2018. Available online: http://english.crcc.cn/col/col21615/index.html (accessed on 28 January 2020).

63. Numbeo. Gas Price in China. 2019. Available online: https://www.numbeo.com/gas-prices/country_result. jsp? country=China (accessed on 28 January 2020).

64. Jiao, J.; Wang, J.; Jin, F.; Dunford, M. Impacts on accessibility of China's present and future HSR network. J. Transp. Geogr. 2014, 40, 123-132. [CrossRef]

65. Kaewunruen, S.; Remennikov, A.M. Experiments into impact behaviour of railway prestressed concrete sleepers. Eng. Fail. Anal. 2011, 18, 2305-2315. [CrossRef]

66. Shanghai Bureau of Statistics. Population. 2015. Available online: http://www.stats-sh.gov.cn/data/toTjnj. xhtml? $y=2013$ (accessed on 28 January 2020).

67. National Bureau of Statistics of China. Population Data from Sample Survey. 2018. Available online: http://data.stats.gov.cn/english/easyquery.htm?cn=E0103 (accessed on 28 January 2020).

68. Nickelsburg, J.; Ahluwalia, S.; Yang, Y. High-Speed Rail Economics, Urbanization and Housing Affordability Revisited: Evidence from the Shinkansen System; UCLA Anderson school of Management: Los Angeles, CA, USA, 2018.

69. Hensher, D.; Li, Z.; Muller, C. The impact of high speed rail on land and property values: A review of market monitoring evidence from eight countries. Road Transp. Res. 2012, 21, 3-14.

70. Liu, C.; Xiong, W. China's Real Estate Market; NBER Working Paper No.25297; National Bureau of Economic Research: Cambridge, MA, USA, 2018; Available online: http://www.nber.org/papers/w25297\% OANATIONAL (accessed on 28 January 2020). 
71. Deng, Y.; Gyourko, J.; Wu, J. Land and House Price Measurement in China; Property Markets and Financial Stability, Bank of International Settlement and Reserve Bank of Australia: Canberra, Australia, 2012.

72. Setsobhonkul, S.; Kaewunruen, S.; Sussman, J.M. Lifecycle Assessments of Railway Bridge Transitions Exposed to Extreme Climate Events. Front. Built Environ. 2017, 3, 35. [CrossRef]

73. Kaewunruen, S.; Alawad, H.; Cotruta, S. A Decision Framework for Managing the Risk of Terrorist Threats at Rail Stations Interconnected with Airports. Safety 2018, 4, 36. [CrossRef]

74. Kaewunruen, S.; Remennikov, A.M.; Murray, M.H. Introducing a new limit states design concept to railway concrete sleepers: An Australian experience. Front. Mater. 2014, 1, 8. [CrossRef]

75. Kaewunruen, S.; Sussman, J.M.; Einstein, H.H. Strategic framework to achieve carbon-efficient construction and maintenance of railway infrastructure systems. Front. Environ. Sci. 2015, 3, 6. [CrossRef]

76. Kaewunruen, S. Enhancing Railway Engineering Student Engagement Using Interactive Technology Embedded with Infotainment. Educ. Sci. 2019, 9, 136. [CrossRef]

77. Kaewunruen, S.; Sresakoolchai, J.; Peng, J. Life Cycle Cost, Energy and Carbon Assessments of Beijing-Shanghai High-Speed Railway. Sustainability 2020, 12, 206. [CrossRef]

78. Kaewunruen, S.; Sussman, J.M.; Matsumoto, A. Grand challenges in transportation and transit systems. Front. Built Environ. 2016, 2, 4. [CrossRef]

(C) 2020 by the authors. Licensee MDPI, Basel, Switzerland. This article is an open access article distributed under the terms and conditions of the Creative Commons Attribution (CC BY) license (http://creativecommons.org/licenses/by/4.0/). 